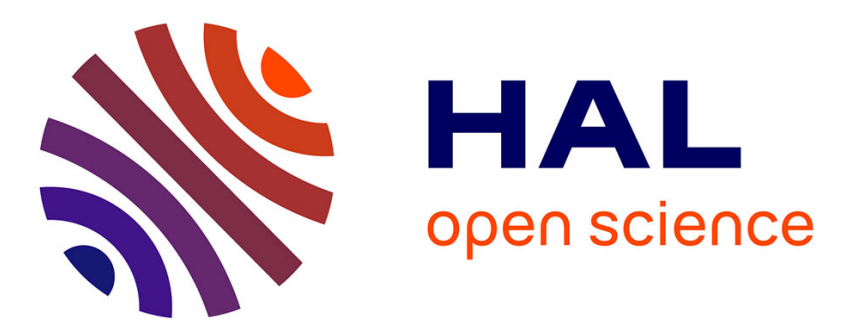

\title{
One channel spatio-temporal inversion of acoustic wave in reverberant cavities
}

\author{
Stefan Catheline, Matthieu Rupin, Philippe Roux
}

\section{To cite this version:}

Stefan Catheline, Matthieu Rupin, Philippe Roux. One channel spatio-temporal inversion of acoustic wave in reverberant cavities. Acoustics 2012, Apr 2012, Nantes, France. hal-00811364

\section{HAL Id: hal-00811364 \\ https://hal.science/hal-00811364}

Submitted on 23 Apr 2012

HAL is a multi-disciplinary open access archive for the deposit and dissemination of scientific research documents, whether they are published or not. The documents may come from teaching and research institutions in France or abroad, or from public or private research centers.
L'archive ouverte pluridisciplinaire HAL, est destinée au dépôt et à la diffusion de documents scientifiques de niveau recherche, publiés ou non, émanant des établissements d'enseignement et de recherche français ou étrangers, des laboratoires publics ou privés. 


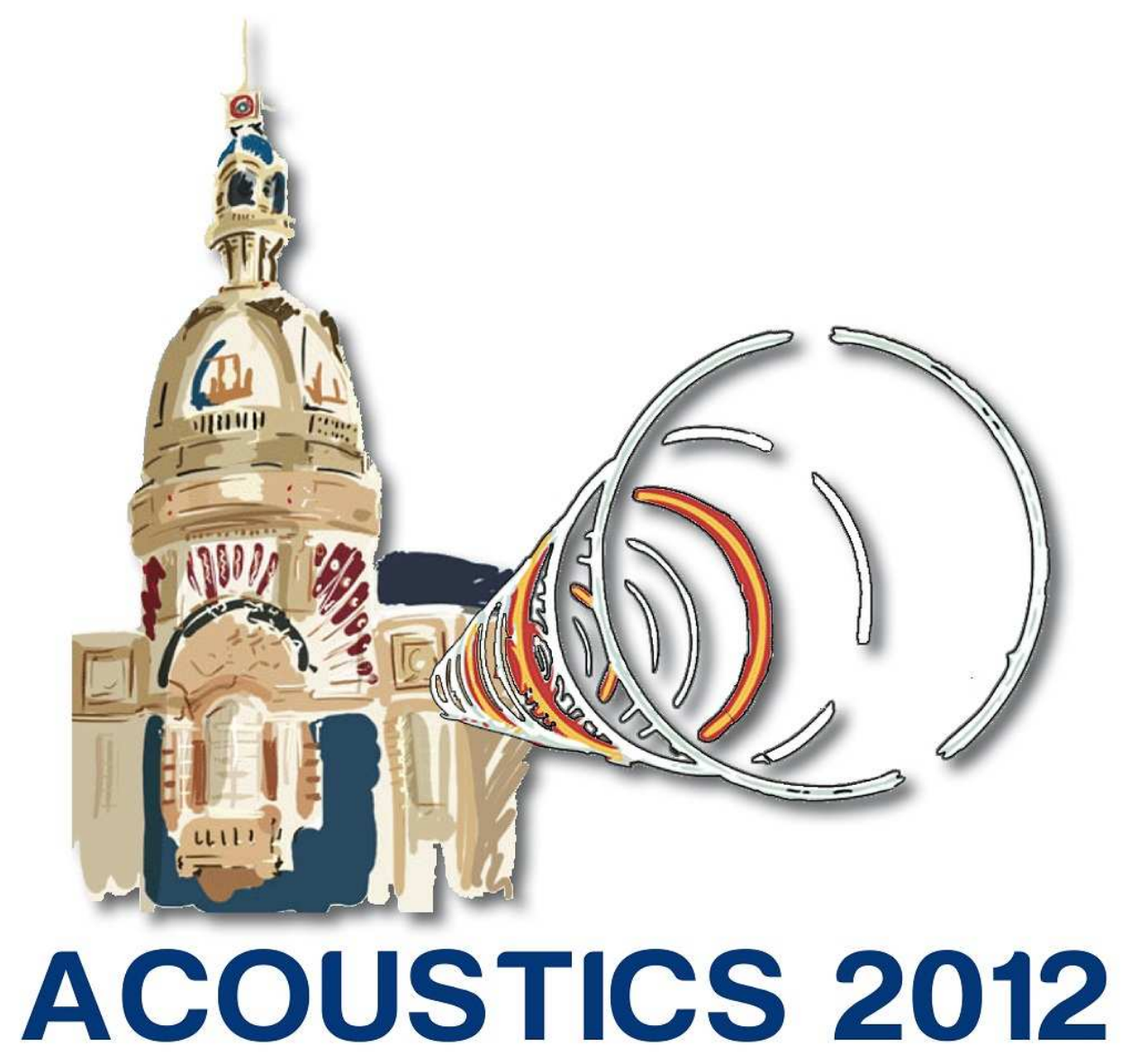

One channel spatio-temporal inversion of acoustic wave in reverberant cavities

S. Catheline, M. Rupin and P. Roux

Institut des Sciences de la Terre, ISTerre BP 53, 38041 Grenoble Cedex 9, France stefan.catheline@obs.ujf-grenoble.fr 